\title{
Physiologic Levels of Uric Acid Inhibit Xanthine Oxidase in Human Plasma
}

\author{
SIDHARTHA TAN, RAFAEL RADI, FRANCISCO GAUDIER, ROY A. EVANS, ARNOLD RIVERA. \\ KATHARINE A. KIRK, AND DALE A. PARKS \\ Departments of Pediatrics [S.T., A.R.J. Obstetrics and G.necology /F.G.], Anesthesiology [R.A.E.. D.A.P.J. and \\ Biostatistics and Biomathematics [K..A.K.]. University of Alahama at Birmingham. Birmingham, Alabama \\ 35233, and Department of Biochemistry /R.R.J. Faculty of Hedicine, the University of the Republic.
}

Montevideo, Uruguay

\begin{abstract}
Xanthine oxidase, a key source of reactive oxygen species, and purine substrates are detected in the circulation after ischemia-reperfusion. High levels of uric acid, produced by a xanthine oxidase-catalyzed reaction, are found in human plasma. We studied whether uric acid could alter xanthine oxidase activity in plasma obtained from eight adults and eight neonates. Known amounts of uric acid were added to xanthine and xanthine oxidasesupplemented buffer and plasma, and the production of uric acid and superoxide was determined. Uric acid, 150 and $300 \mu \mathrm{M}$, decreased the oxidation of xanthine to uric acid in adult plasma by $37.5 \pm 5.6$ and $48.9 \pm 6.1 \%$ and formation of superoxide by $23.2 \pm 1.9$ and $32.0 \pm 2.3 \%$, respectively, compared with plasma without uric acid. In newborn plasma, a similar pattern and extent of inhibition was observed. Superoxide formation, however, was inhibited to a greater extent than in adult plasma. Endogenous xanthine oxidase was detected in newborn plasma in nine additional neonates using IIPLC. These results indicate that uric acid is an effective inhibitor of the formation of superoxide and hydrogen peroxide by xanthine oxidase at the levels found in human plasma. Plasma uric acid may play an important role in attenuating the oxidant-mediated tissue damage caused by xanthine oxidase released into the circulation during ischemia-reperfusion. (Pediatr Res 34: 303-307, 1993)
\end{abstract}

\section{Abbreviations}

$\mathrm{H}_{2} \mathrm{O}_{2}$, hydrogen peroxide

$\mathrm{O}_{2}^{-}$, superoxide

SOD, superoxide dismutase

UA, uric acid

XDH, xanthine dehydrogenase

XO, xanthine oxidase

UA, because of its capacity to act as an antioxidant and freeradical scavenger, plays an important role in biologic fluids (13). Plasma levels of UA increase with advancing age, with the lowest levels of UA seen in the childhood years (4). UA levels are, however, elevated in premature infants, varying inversely with gestational age (4). XO, the enzyme involved in the produc-

Received July 20, 1992; accepted April 23, 1993.

Correspondence and reprint requests: Dale A. Parks, Ph.D., Department of Anesthesiology, 619 South 19th St.. University of Alabama at Birmingham. Birmingham, AL. 35233-6810

Supported by the National Institutes of Health Grant R29-DK-3868I and P01HL-48676, and Grant AHA.870029 from the Alabama Affiliate of the American Heart Association. tion of UA, is a source of production of the oxidants, $\mathrm{O}_{2}^{-}$, and $\mathrm{H}_{2} \mathrm{O}_{2}$. These oxidants may be involved in the pathogenesis of the tissue injury associated with many disease states, including reperfusion of ischemic tissues (5). XO activity has been detected in tissues at a gestational age $(6,7)$ that may precede the maturation of enzymatic antioxidant defenses to adult levels in tissues (8), implicating the need for nonenzymatic antioxidant defenses. Xanthine oxidoreductase (EC 1.2.3.2), existing in healthy cells as the $\mathrm{NAD}^{+}$-reducing $\mathrm{XDH}$, is converted to oxygen radicalproducing $\mathrm{XO}$ during ischemia (5). XDH and $\mathrm{XO}$ are released in the circulation in many animal models $(9,10)$, in hemorrhagic shock (11), after ischemia (12), and after tourniquet injury to a human limb (13). Cellular ATP is catabolized during ischemia or oxygen deficiency, resulting in elevated hypoxanthine levels in plasma during tissue hypoxia (14). Upon reperfusion (reoxygenation), $\mathrm{XO}$ can react with purine substrates (hypoxanthine or xanthine) and molecular oxygen to produce UA and, in oneand two-electron reduction steps (univalent and divalent flux), $\mathrm{O}_{2}^{-}$and $\mathrm{H}_{2} \mathrm{O}_{2}$, respectively $(15-17)$.

The absence of enzymes responsible for further metabolism of UA in humans results in plasma UA concentrations as high as $500 \mu \mathrm{M}(4)$. We asked whether UA could have a biologic role, other than that of an antioxidant, as an inhibitor of circulating $\mathrm{XO}$ activity. Although UA has been known to inhibit $\mathrm{XO}$ in alkaline chemical solutions and at high concentrations $(\geq 670$ $\mu \mathrm{M})(18,19)$, little is known about its behavior in biologic fluids with normal $\mathrm{pH}$. We hypothesized that the levels of UA found in plasma would inhibit XO activity in plasma. This study investigated the effect of UA in plasma on the oxidation of xanthine to UA and the amount of univalent-divalent flux. We also compared the effect of UA inhibition in newborn plasma with that in adults to determine whether UA was an effective inhibitor of $\mathrm{XO}$ in newborn plasma.

\section{MATERIALS AND METHODS}

Bovine milk XO was obtained from Calbiochem (La Jolla, CA). Stock solutions were made daily by centrifuging $25 \mu \mathrm{L}$ of $\mathrm{XO}$ suspended in $2 \mathrm{M}\left(\mathrm{NH}_{4}\right)_{2} \mathrm{SO}_{4}$ for $2 \mathrm{~min}$ in a microcentrifuge at $5000 \times g$. The supernatant was discarded and the sedimented crystals resuspended in $50 \mathrm{mM}$ potassium phosphate buffer, 0.1 $\mathrm{mM}$ EDTA, $\mathrm{pH}$ 7.4. Bovine erythrocyte $\mathrm{Cu}-\mathrm{Zn}$ SOD was obtained from Grünenthal (Aachen, Germany). All other reagents were obtained from Sigma Chemical Co. (St. Louis, MO) except acetonitrile, which was obtained from Baxter Healthcare Corp. (McGaw Park, IL). Blood was collected from eight healthy adult volunteers (20-40 y old) and eight healthy full-term newborn babies at delivery. The sites of blood collection were the antecubital vein in adults and the umbilical cord artery and vein in neonates. Blood was pipetted into heparinized tubes, placed on ice, and centrifuged immediately. The plasma was chromato- 
graphed on a Sephadex G-25 column to remove endogenous purines and low molecular weight inhibitors (postcolumn plasma). Plasma protein levels were measured before and after the column procedure by the bicinchoninic acid protein assay (Pierce Chemical, Rockford, IL). The concentration of plasma was adjusted so that the final concentration of plasma protein in the cuvette was always $15 \mathrm{~g} / \mathrm{L}( \pm 0.1 \mathrm{~g} / \mathrm{L})$. This was done to control for the variability of the dilution from the chromatography of different plasma samples. Measurements of oxidation of xanthine to $\mathrm{UA}$ and $\mathrm{O}_{2}^{-}$production by $\mathrm{XO}$ were made in the presence or absence of plasma on a Gilford spectrophotometer (Ciba Corning Diagnostics, Oberlin, OH). A mean of three measurements was obtained for every assay.

$X O$ activity measurement. The activity of $\mathrm{XO}$ was measured daily by monitoring the absorbance change at $292 \mathrm{~nm}$ (for UA production) in the presence of $50 \mu \mathrm{M}$ xanthine and $50 \mathrm{mM}$ potassium phosphate buffer with $0.1 \mathrm{mM}$ EDTA (pH 7.4) (20). The amount of XO was adjusted to a final activity of $5 \mathrm{mU} / \mathrm{mL}$ $( \pm 0.02 \mathrm{mU} / \mathrm{mL})$.

In the measurements involving plasma, postcolumn plasma was mixed with $50 \mathrm{mM}$ potassium phosphate buffer (pH 7.4) with $0.1 \mathrm{mM}$ EDTA, $5 \mathrm{mU} / \mathrm{mL} \mathrm{XO}, 50 \mu \mathrm{M}$ xanthine, and $0-$ $300 \mu \mathrm{M} \mathrm{UA}$ at $25^{\circ} \mathrm{C}$. The amount of UA formed from xanthine was quantified by using a spectrophotometer and monitoring the absorbance at $308.5 \mathrm{~nm}(21)$. This wavelength was chosen because plasma proteins cause less interference with the detection of UA at this wavelength than at $292 \mathrm{~nm}$. The extinction coefficient of UA at $308.5 \mathrm{~nm}$ was $3085 \mathrm{M}^{-1} \cdot \mathrm{cm}^{-1}$ at $25^{\circ} \mathrm{C}$ and $\mathrm{pH}$ 7.4. Because of limitations in the amount of blood obtained from newborn samples, we were able to study only three concentrations of UA in all subjects. In the umbilical artery group, six subjects were studied because we were unable to obtain blood from two of the subjects. With UA concentrations of $500 \mu \mathrm{M}$, absorbance values greater than 2 were obtained in plasma that exceeded the linearity of the spectrophotometer. This resulted in unacceptable variations in the rate of change of absorbance. In buffer, UA concentrations of $500 \mu \mathrm{M}$ did not present any problems. An intermediate concentration of $200 \mu \mathrm{M}$ was studied in some plasma samples to confirm the pattern of inhibition and is not presented in the figures.

$\mathrm{O}_{2}^{-}$determination. $\mathrm{O}_{2}^{-}$was determined from the SOD-inhibitable reduction of ferricytochrome $c$ at $550 \mathrm{~nm}$, in the presence and absence of postcolumn plasma. Postcolumn plasma was mixed with $50 \mathrm{mM}$ potassium phosphate buffer $(\mathrm{pH} 7.4)$ with $0.1 \mathrm{mM}$ EDTA, $50 \mu \mathrm{M}$ xanthine, $5 \mathrm{mU} / \mathrm{mL}$ XO, $100 \mu \mathrm{M}$ ferricytochrome $c$, and $0-300 \mu \mathrm{M}$ UA, at $25^{\circ} \mathrm{C}$. The reduction of ferricytochrome $c$ from non- $\mathrm{O}_{2}{ }^{-}$sources was determined by the addition of $1 \mu \mathrm{M}$ SOD to the above reaction. Thus, the amount of $\mathrm{O}_{2}^{-}$formed from the reaction of $\mathrm{XO}$ with xanthine was obtained from the difference of the two values, with and without SOD.

Endogenous XO activity in newborn plasma. Nine additional healthy full-term neonates were studied for the presence of circulating XO. We were unable to detect endogenous XO activity consistently in newborn plasma with use of a spectrophotometer because its lower limit is $0.5 \mathrm{mU} / \mathrm{mL}$ plasma. Thus, we developed an HPLC method with electrochemical detection that could detect one-thousandth the activity detected by the spectrophotometric method. Plasma was obtained from both umbilical artery and vein. Total XDH $+\mathrm{XO}$ and $\mathrm{XO}$ activity was determined by the addition of xanthine $(75 \mu \mathrm{M})$ to postcolumn plasma, with and without the addition of $500 \mu \mathrm{M} \mathrm{NAD}^{+}$, respectively. The plasma was incubated at $37^{\circ} \mathrm{C}$ for $60 \mathrm{~min}$ and the reaction stopped by addition of cold $99.9 \%$ acetonitrile. The precipitate was removed by centrifugation $(6000 \times g, 20 \mathrm{~min})$ and the supernatant evaporated by a Speed Vac evaporator (Savant Instruments, Farmingdale, NY). The residue from evaporation was resuspended to the original plasma volume with 50 $\mathrm{mM}$ sodium acetate buffer, $\mathrm{pH} 4.75$. Fifty $\mu \mathrm{L}$ was then injected onto a $5-\mu \mathrm{m}$ C -18 column $(15 \times 0.46 \mathrm{~cm})$ (Perkin-Elmer, Nor- walk, CT) with a mobile phase of $50 \mathrm{mM}$ sodium acetate buffer, $\mathrm{pH} 4.75$, and a flow rate of $1.0 \mathrm{~mL} / \mathrm{min}$. The amount of UA formed from xanthine was quantified using an electrochemical detector (Coulochem 5100A, ESA, Bedford, MA). The UA in plasma was confirmed by using the retention time of UA standard in $50 \mathrm{mM}$ sodium acetate buffer, $\mathrm{pH} 4.75$. The quantities of UA were determined by comparison of the peak areas to those of standards. A unit of enzyme activity was defined as $1 \mu \mathrm{mol}$ of UA formed per minute at $37^{\circ} \mathrm{C}$ and $\mathrm{pH} 7.4$.

Statistical analysis. Analysis was done by paired $t$ test for comparison of buffer and plasma and by two-sample $t$ test for comparison of two types of plasma. Analysis of the effect of UA on xanthine oxidation and $\mathrm{O}_{2}{ }^{-}$formation in both buffer and plasma was conducted with repeated measures analysis of variance (22). For studies in buffer that included $0-500 \mu \mathrm{M}$ of UA, a nonlinear regression procedure using a least-square estimate of the parameters of a nonlinear model was used (22). The model, $y=a\left(e^{-b x}\right)+c$, was fitted by a modified Gauss-Newton method, where $y=$ xanthine oxidation or $\mathrm{O}_{2}^{-}$formation, $\mathrm{x}=\mathrm{UA}$ concentration, and $a, b$, and $c$ are partial derivatives of the model. For the analysis of the similarity of the trend between xanthine oxidation and $\mathrm{O}_{2}^{-}$formation, a nonlinear model was fitted including the adjusted values of xanthine oxidation and $\mathrm{O}_{2}{ }^{-}$ formation. From the residual sum of squares of the three models, an $F$ statistic was calculated. An alpha error of less than 0.05 was considered significant. All results are expressed as mean $\pm \mathrm{SD}$.

\section{RESULTS}

Inhibition in adult plasma. UA inhibited XO activity in plasma at 150 and $300 \mu \mathrm{M}$ by $37.5 \pm 5.6$ and $48.9 \pm 6.1 \%$, respectively, compared with plasma without UA. In buffer, a similar pattern was found: XO activity at the same UA concentrations was 32.4 \pm 2.5 and $41.7 \pm 3.0 \%$, respectively, less than the activity without UA (Fig. 1). The decrease in $\mathrm{O}_{2}{ }^{-}$production by UA was $23.2 \pm$ 1.9 and $32.0 \pm 2.3 \%$ at 150 and $300 \mu \mathrm{M}$, respectively, in plasma. In buffer, the decrease was $21.0 \pm 3.2$ and $30.5 \pm 2.7 \%$, respectively, at the same concentrations (Fig. 2).

Inhibition in newborn plasma. UA decreased the xanthine

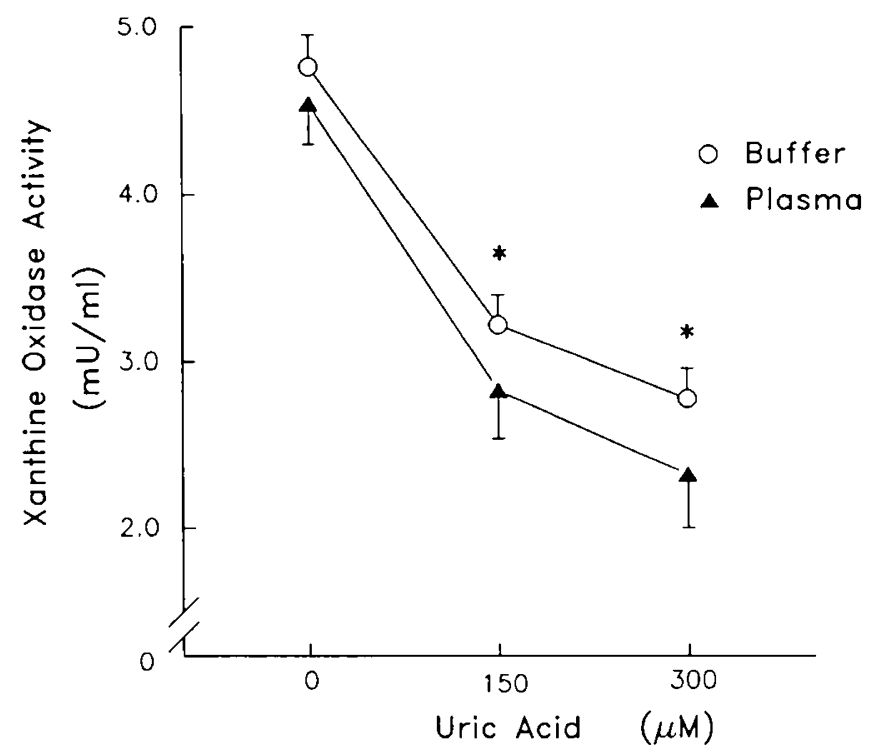

Fig. 1. Comparison of $X O$ activity $( \pm S D)$, determined by xanthine to UA turnover, in adult plasma $(n=8)$ and buffer (paired with plasma, $n=8$ ). Each sample was assayed in triplicate. UA caused a decrease in $\mathrm{XO}$ activity with increasing concentration of $\mathrm{UA}$ in both plasma (analysis of variance, $p<0.0001)$ and buffer $(p<0.0001)$. The pattern of inhibition is not different between plasma and buffer groups (repeated measures analysis of variance, NS). At 150 and $300 \mu \mathrm{M}$ UA concentrations, plasma activity is less than that in buffer $\left({ }^{*}, t\right.$ test, $\left.p<0.05\right)$. 


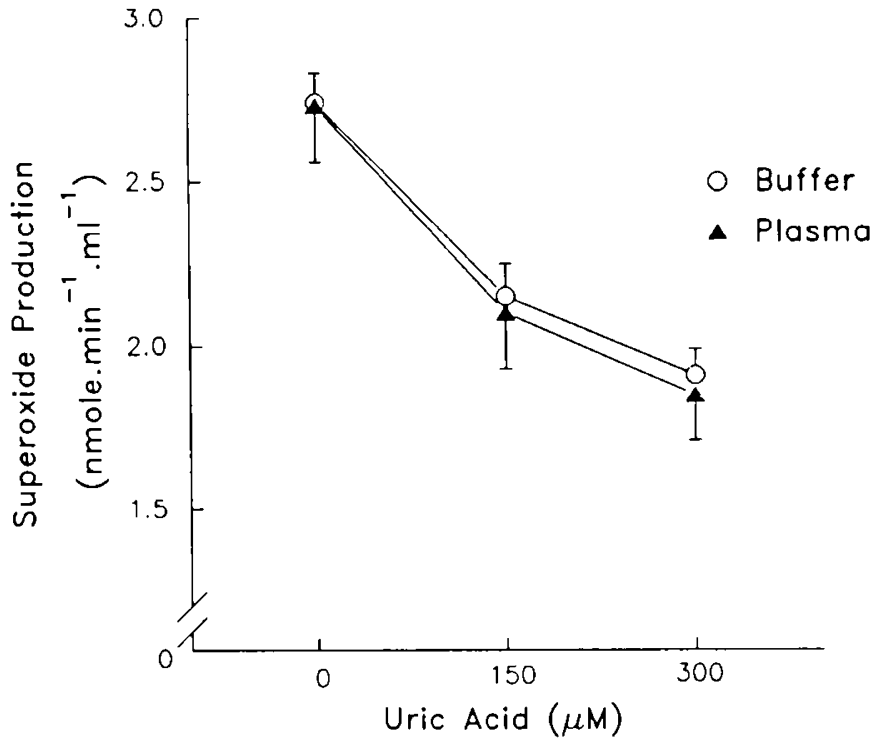

Fig. 2. Comparison of $\mathrm{O}_{2}^{-}$formation by $\mathrm{XO}( \pm \mathrm{SD})$ in adult plasma and buffer (see Fig. 1 for details). UA caused a decrease in formation of $\mathrm{O}_{2}{ }^{-}$in both plasma $(p<0.0001)$ and buffer $(p<0.0001)$. There was no difference in the pattern of inhibition or at each UA concentration between the plasma and buffer groups.

oxidation (XO activity) and the production of $\mathrm{O}_{2}^{-}$by $\mathrm{XO}$ in both newborn plasma and buffer (Fig. 3). UA, $200 \mu \mathrm{M}$, in both plasma and buffer confirmed the pattern of inhibition (data not shown). Only umbilical vein plasma results are shown. Umbilical artery plasma studies $(n=6)$ showed no significant difference from the umbilical vein plasma studies.

Comparison of trends of inhibition in buffer. In buffer, xanthine oxidation and $\mathrm{O}_{2}^{-}$formation at $500 \mu \mathrm{M}$ UA was also studied in addition to 0,150 , and $300 \mu \mathrm{M}$. A nonlinear trend was noted in both the xanthine oxidation and $\mathrm{O}_{2}^{-}$formation, as expected. Using a nonlinear regression procedure, the decrease of xanthine oxidation by UA was not significantly different from the decrease of $\mathrm{O}_{2}{ }^{-}$formation by UA. We were unable to evaluate the effect of $500 \mu \mathrm{M}$ UA in plasma because of unacceptable variations in rate of change of absorbance on the spectrophotometer at these high absorbance values (absorbance values $\geq 2$ ).

Comparison of adult and newborn plasma. Although the pattern of XO inhibition by different concentrations of UA was not different between plasma and buffer, there were differences noted in XO activity at individual UA concentrations. Less XO activity was found in adult plasma than in buffer at 150 and $300 \mu \mathrm{M}$, in contrast to the findings in newborn plasma of increased $\mathrm{XO}$ activity compared with buffer (Figs. 2 and $3 A$ ). Less $\mathrm{O}_{2}{ }^{-}$production occurred at all concentrations of newborn plasma compared with buffer (Fig. 3B). When expressed as a percentage of the buffer control, $\mathrm{XO}$ activity was significantly higher in newborn plasma than in adult plasma (Fig. 4). $\mathrm{O}_{2}^{-}$produced by $\mathrm{XO}$ in newborn plasma was significantly lower than in adult plasma.

Univalent flux describes single electron transfers from the enzyme $\mathrm{XO}$ to $\mathrm{O}_{2}$ to form $\mathrm{O}_{2}^{-}$compared with divalent flux, which describes the transfer of two electrons to $\mathrm{O}_{2}$ to form $\mathrm{H}_{2} \mathrm{O}_{2}$ (15-17). UA increased the univalent flux in adult plasma in a dose-dependent fashion but did not change the univalent flux significantly in newborn plasma (Table 1).

Endogenous XO in newborn plasma. To explain the apparent discrepancy between adult and newborn plasma, we tested for the presence of endogenous $\mathrm{XO}$ in newborn plasma. We found elevation of total (XDH $+\mathrm{XO}$ ) and $\mathrm{XO}$ activity in both umbilical artery and umbilical vein plasma (Table 2 ).

\section{DISCUSSION}

The present study indicates that the high levels of UA (150$500 \mu \mathrm{M}$ ) normally found in human plasma constitute an impor-
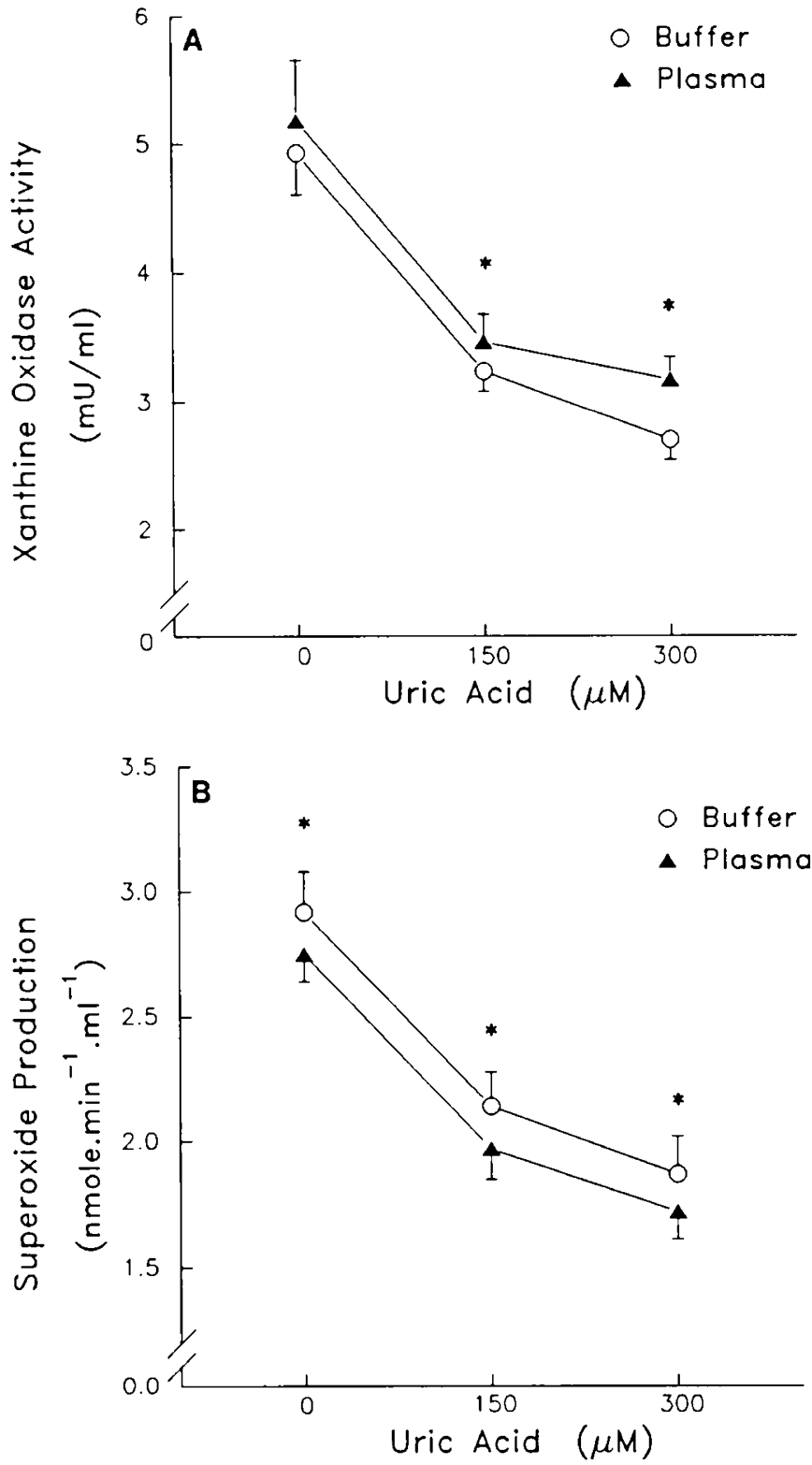

Fig. 3. Comparison of $\mathrm{XO}$ activity, determined by xanthine oxidation $(A)$, and $\mathrm{O}_{2}^{-}$production by $\mathrm{XO}(B)$ in newborn plasma $(n=8)$ and buffer (paired with newborn plasma, $n=8$ ). Each sample was assayed in triplicate. UA caused a decrease in xanthine oxidation and production of $\mathrm{O}_{2}^{-}$in both newborn plasma and buffer $(p<0.0001$ in all cases). There was no difference between the plasma and buffer groups in $A$ or $B$. Note differences between plasma and buffer at each UA concentration $(*, p<0.05)$.

tant defense mechanism by which the production of reactive oxygen metabolites by circulating $\mathrm{XO}$ is attenuated. Circulating $\mathrm{XO}$ has been demonstrated in the circulation after ischemiareperfusion in many animal models $(9-11)$ and in humans after upper limb ischemia $(12,13)$ and liver transplantation (23). XO has also been detected in significant quantities in the systemic circulation secondarily to diverse pathologic processes including adult respiratory distress syndrome and thermal injury $(24,25)$. We demonstrated that UA inhibits the oxidation of xanthine to $\mathrm{UA}$ and decreases the formation of $\mathrm{O}_{2}^{-}$by XO.

The levels of hypoxanthine, another substrate of $\mathrm{XO}$, increases to $\sim 25 \mu \mathrm{M}$ in hypoxia in the newborn (14). In our study, excess substrate (xanthine) concentration was selected to ensure that $\mathrm{XO}$ activity was at $\mathrm{V}_{\max }$. Substrate excess in plasma mimics the worst clinical situation where the release of substrate is far in 


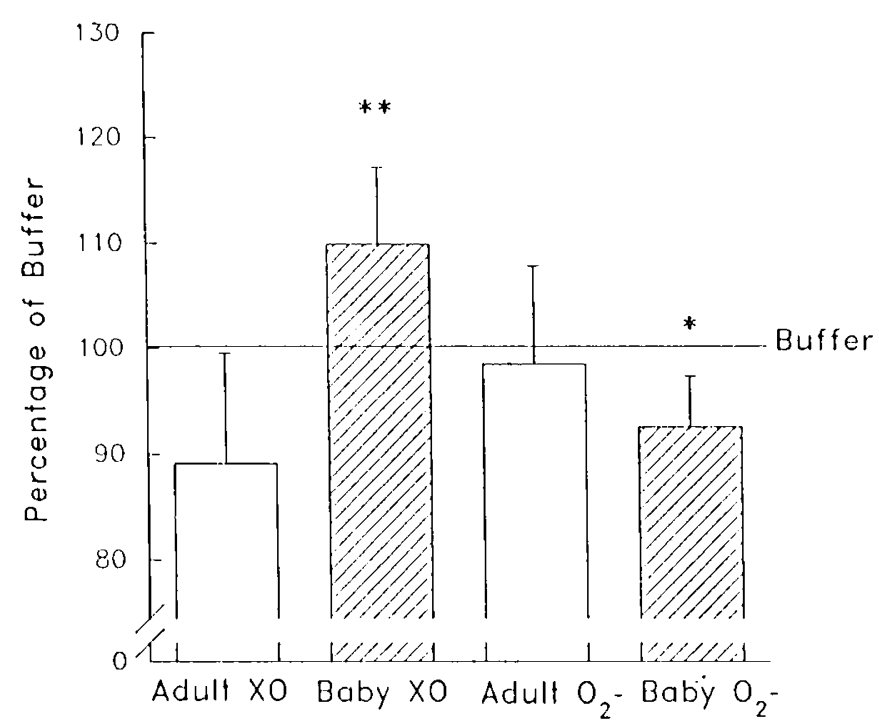

Fig. 4. Comparison between adult and newborn plasma of XO activity $\left({ }^{* *}, p<0.0001\right)$ and $\mathrm{O}_{2}^{-}$formation $\left({ }^{*}, p<0.01\right)$, expressed as percentage of corresponding buffer controls.

Table 1. Univalent flux, expressed as percentage of total electron flux, in adult and newborn plasma with and without uric acid*

\begin{tabular}{ccc}
\hline $\begin{array}{c}\text { Uric acid concentration } \\
(\mu \mathrm{M})\end{array}$ & $\begin{array}{c}\text { Adult plasma } \\
(\%)\end{array}$ & $\begin{array}{c}\text { Newborn plasma } \\
(\%)\end{array}$ \\
\hline 0 & $30.1 \pm 2.5$ & $25.1 \pm 1.0$ \\
150 & $37.4 \pm 5.5$ & $26.9 \pm 2.3$ \\
300 & $40.8 \pm 7.4$ & $26.2 \pm 2.4$ \\
\hline
\end{tabular}

Uric acid increased univalent flux in adult plasma in a dose-dependent fashion $(p<0.004)$ but did not change univalent flux significantly in newborn plasma.

Table 2. Endogenous $X D H+X O$ and $X O$ activity in plasma obtained at delivery from umbilical cord artery and vein

\begin{tabular}{lcc}
\hline & Umbilical artery & Umbilical vein \\
\hline Total $(\mathrm{XDH}+\mathrm{XO})(\mu \mathrm{U} / \mathrm{mL})$ & $8.9 \pm 2.5$ & $9.6 \pm 2.1$ \\
$\mathrm{XO}(\mu \mathrm{U} / \mathrm{mL})$ & $2.4 \pm 0.5$ & $2.5 \pm 0.3$ \\
\hline
\end{tabular}

excess of the $\mathrm{Km}$ (substrate concentration at half-maximal velocity) of XO $(4-6 \mu \mathrm{m})$. Lower substrate concentrations, on the other hand, result in submaximal velocities for XO activity (26). This, along with high UA concentrations, produces a greater net inhibition of $\mathrm{XO}$ activity. Thus, UA may play a greater protective role in normal neonates and in conditions of mild hypoxia.

$\mathrm{UA}$ is an important antioxidant and free radical scavenger in biologic systems $(2,3)$. Antioxidants may play an important role in the slowing of the aging process $(1,27,28)$. Elevations in plasma UA in man are found in adulthood and in premature neonates (4). In premature babies, plasma UA levels have an inverse relationship with gestational age. The more premature the baby, the more elevated is the UA level in plasma (4). After birth, UA levels drop, with the lowest concentrations being found in the school age years, and then increase in the teen-age years through adulthood. Thus, it is interesting to note that elevations in plasma UA occur at the ends of the life span in man. The increases coincide with periods of oxidant stress (in adulthood) or with periods of relative vulnerability to oxidants (premature gestation).

The levels of many antioxidant enzymes, such as SOD, catalase, and glutathione peroxidase, increase only close to the time of delivery and reach adult levels only after birth $(8,29)$. However, the oxidant-generating enzyme, $\mathrm{XO}$, is detected in liver and

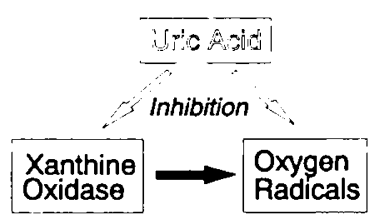

Fig. 5. UA is both an antioxidant as well as an inhibitor of $\mathrm{XO}$ in plasma.

intestine as early as $20 \mathrm{wk}$ of gestation $(6,7)$. The capacity for the generation of reactive oxygen species may be present at an earlier stage of development than the appearance of adequate levels of antioxidant enzymes (29). Thus, UA may play an important protective role, not only as an antioxidant, but as an inhibitor of $\mathrm{XO}$ in premature babies. Further work is in progress to elucidate the relationship between the oxidant-generating systems and antioxidant levels during development in humans.

$\mathrm{H}_{2} \mathrm{O}_{2}$ and $\mathrm{O}_{2}^{-}$are two of the reduced species formed by the reaction of XO with xanthine or hypoxanthine. The amount of reduction in $\mathrm{O}_{2}{ }^{-}$formation (univalent reduction) is less than the inhibition of xanthine oxidation to UA by $\mathrm{XO}$. This suggests that the extent of decrease in $\mathrm{H}_{2} \mathrm{O}_{2}$ formation by $\mathrm{XO}$ (divalent reduction) is greater than the extent of decrease in univalent reduction. Therefore, less $\mathrm{H}_{2} \mathrm{O}_{2}$ is formed than $\mathrm{O}_{2}{ }^{-}$in the presence of UA.

$\mathrm{XO}$ levels were consistently higher in newborn plasma and lower in adult plasma than measured in buffer. This is the first study that has demonstrated the presence of endogenous $\mathrm{XO}$ in normal newborn plasma, but the levels detected were too low to explain the difference between adult and newborn plasma. No significant difference in XO levels was found at zero UA concentration. Eight percent of plasma $\operatorname{IgG}$ from healthy adult humans has been found to be immunoreactive with $\mathrm{XO}$ and to partially inhibit enzyme activity (30). It is not known whether anti-XO IgG levels differ in newborn plasma. The amount of univalent flux was also lower in newborn plasma than in adult plasma. This would imply that the ratio of $\mathrm{H}_{2} \mathrm{O}_{2}$ to $\mathrm{O}_{2}^{-}$produced by $\mathrm{XO}$ is higher in newborn plasma than in adult plasma. Increasing UA concentrations seemed to increase the univalent flux in adult plasma but not in newborn plasma. Further investigations are needed to elucidate the mechanism of these differences.

The role of UA can be summarized as both a direct scavenger of oxygen radicals as well as an inhibitor of the formation of $\mathrm{O}_{2}^{-}$ and $\mathrm{H}_{2} \mathrm{O}_{2}$ by XO (Fig. 5) at the levels found in human plasma.

Acknowledgment. This manuscript is dedicated to the memory of Roy Alan Evans, who provided invaluable assistance in this research.

\section{REFERENCES}

1. Cutler RG 1984 Urate and ascorbate: their possible roles as antioxidants in determining longevity of mammalian species. Arch Gerontol Geriatr 3:321348

2. Becker BF, Reinholz N, Leipert B, Raschke P, Permanetter B, Gerlach E 1991 Role of uric acid as endogenous radical scavenger and antioxidant. Chest 100(suppl 3): 176S-181S

3. Sevanian A, Davies KJA. Hochstein P 1991 Serum urate as an antioxidant for ascorbic acid. Am J Clin Nutr 54:1129S-1134S

4. Baldree LA, Stapleton FB 1990 Uric acid metabolism in childhood. Pediatr Clin North Am 37:391-418

5. Granger DN, Hollwarth ME, Parks DA 1986 Ischemia-reperfusion injury: role of oxygen-derived free radicals. Acta Physiol Scand Suppl 548:47-63

6. Winkler C. Tan S, Wheat JK. Parks DA 1990 Xanthine oxidase activity in human fetal tissues. Pediatr Res 27:231 A(abstr)

7. Vettenranta K, Raivio KO 1990 Xanthine oxidase during human fetal development. Pediatr Res 27:286-288

8. Frank L, Sosenko IRS 1987 Prenatal development of lung antioxidant enzymes in four species. J Pediatr 110:106-110

9. Yokoyama Y, Beckman JS, Beckman TK. Wheat JK, Cash TG, Freeman BA, Parks DA 1990 Circulating xanthine oxidase: potential mediator of ischemic injury. Am J Physiol 258:G564-G570

10. Caty MG, Schmeling DJ, Friedl HP, Oldham KT, Guice KS, Till GO 1990 Histamine: a promoter of xanthine oxidase activity in intestinal ischemia/ reperfusion. J Pediatr Surg 25:218-223 
11. Parks DA, Yokoyama Y. Tan S, Dickens E, Cash TG 1992 Xanthine oxidase activity in the circulation of a rat following hemorrhagic shock. Free Rad Biol Med (in press)

12. Friedl HP, Smith DJ, Till GO, Thompson PD, Louis DS, Ward PA 1990 Ischemia-reperfusion in humans: appearance of xanthine oxidase activity. Am J Pathol 136:491-495

13. Friedl HP, Till GO, Trentz O, Ward PA 1991 Role of oxygen radicals in tourniquet-related ischemia-reperfusion injury of human patients. Klin Wochenschr 69:1109-1112

14. Saugstad OD 1975 Hypoxanthine as a measurement of hypoxia. Pediatr Res 9:158-161

15. Bray RC 1975 Molybdenum iron-sulfur favin hydroxylases and related enzymes. In: Boyer EP (ed) The Enzymes, Vol XII, Part B. Academic Press, New York, pp 300-419

16. Porras AG, Olson JS, Palmer G 1981 The reaction of reduced xanthine oxidase with oxygen. Kinetics of peroxide and superoxide formation. J Biol Chem 256:9096-9103

17. Hille R, Massey V 1981 Studies on the oxidative half-reaction of xanthine oxidase. J Biol Chem 256:9090-9095

18. Dixon M, Thurlow S 1924 Studies on xanthine oxidase. II. The dynamics of the oxidase system. Biochem J 18:976-988

19. Barber MJ, Siegel LM 1982 Oxidation-reduction potentials of molybdenum flavin and iron-sulfur centers in milk xanthine oxidase: variation with $\mathrm{pH}$. Biochemistry 21:1638-1647

20. Stirpe F, Della Corte E 1969 The regulation of rat liver xanthine oxidase: conversion in vitro of the enzyme activity from dehydrogenase (type D) to oxidase (type O). J Biol Chem 244:3855-3863

21. Radi R, Bush KM Cosgrove TP, Freeman BA 1991 Reaction of xanthine oxidase-derived oxidants with lipid and protein of human plasma. Arch Biochem Biophys 286:117-125

22. SAS Institute Inc 1988 SAS/STAT User's Guide, Release 6.03 Edition. SAS Institute Inc, Cary, NC

23. Tan S, Gelman S, Poplawski SC, Baldwin S, Sweeney SD, Parks DA 1992 Xanthine oxidase: release into the circulation following human liver transplantation. Gastroenterology 102:A246(abstr)

24. Grum CM, Ragsdale RA, Ketai LH, Simon RH 1991 Plasma xanthine oxidase activity in patients with adult respiratory distress syndrome. J Crit Care $2: 22-26$

25. Friedl HP, Till GO, Trentz O, Ward PA 1989 Roles of histamine, complement and xanthine oxidase in thermal injury of skin. Am J Pathol 135:203-217

26. Radi R, Tan S, Prodanov E, Evans RA, Parks DA 1992 Inhibition of xanthine oxidase by uric acid and its influence on superoxide radical production. Biochim Biophys Acta 1122:178-182

27. Keilin J 1959 The biological significance of uric acid and guanine excretion. Biol Rev 34:265

28. Cutler RG 1991 Antioxidants and aging. Am J Clin Nutr 53:373S-379S

29. Engelhardt EL, Beggs JC, Neu J 1987 Maturation of antioxidant enzymes in rat small intestine: lack of glucocorticoid stimulation. J Pediatr 1 1 1:459-463

30. Bruder G, Jarasch ED, Heid HW 1984 High concentrations of antibodies to xanthine oxidase in human and animal sera. J Clin Invest 74:783-794 